\title{
Persistent Organic Pollutant-Mediated Insulin Resistance
}

\author{
Yeon A. Kim ${ }^{1,2,3}$, , Joon Beom Park ${ }^{1}$, Min Seok Woo ${ }^{4}$, Sang Yeob Lee ${ }^{1,5}$, Hye Young Kim ${ }^{1}$ \\ and Young Hyun Yoo $1, *$ (D) \\ 1 Department of Anatomy and Cell Biology and Mitochondria Hub Regulation Center, Dong-A University \\ College of Medicine, Busan 49201, Korea; keivin@naver.com (Y.A.K.); csplen1990@dau.ac.kr (J.B.P.); \\ leesy@dau.ac.kr (S.Y.L.); dolph02@dau.ac.kr (H.Y.K.) \\ 2 Department of Anesthesiology and Pain Medicine, Gyeongsang National University Changwon Hospital, \\ Changwon 51472, Korea \\ 3 Institute of Health Sciences, School of Medicine, Gyeongsang National University, Jinju 52727, Korea \\ 4 Department of Convergence Medical Science, Gyeongsang National University, Jinju 52727, Korea; \\ whitewms@naver.com \\ 5 Department of Rheumatology, Dong-A University College of Medicine, Busan 49201, Korea \\ * Correspondence: yhyoo@dau.ac.kr; Tel.: +82-51-240-2637
}

Received: 21 December 2018; Accepted: 31 January 2019; Published: 3 February 2019

\begin{abstract}
Persistent organic pollutants (POPs) such as organochlorine (OC) pesticides, polychlorinated biphenyls (PCBs), polychlorinated dibenzo-p-dioxins (PCDDs), and polychlorinated dibenzofurans (PCDFs) have become wide-spread environmental contaminants as a consequence of their extensive use, long-range transport, and persistence. Because POPs are highly resistant to metabolic degradation, humans bioaccumulate these lipophilic and hydrophobic pollutants in fatty tissues for many years. Previous studies have demonstrated that POPs including PCBs are involved in the development of diabetes mellitus (DM) type 2 and insulin resistance. Numerous epidemiological studies suggest an association between POP burden and DM type 2/metabolic syndrome. In addition, several experimental studies have provided additional evidence supporting the association between POP exposure and DM type 2 or insulin resistance. Epidemiological and experimental studies have provided compelling evidence indicating that exposure to POPs increases the risk of developing insulin resistance and metabolic disorders. However, the detailed molecular mechanism underlying POP-induced insulin resistance is yet to be elucidated. In this article, we review literature that has reported on the association between POP burden and insulin resistance and the mechanism underlying POP-induced insulin resistance, and discuss implications for public health.
\end{abstract}

Keywords: insulin resistance; persistent organic pollutants

\section{Persistent Organic Pollutants (POPs)}

Numerous chemicals produced by humans intentionally or unintentionally have been released into ecosystems since the Industrial Revolution, and the propensity for these toxic chemicals to not degrade has been reported consistently since the 20th century. The most representative chemicals showing a well-known causal relationship are POPs [1].

POPs contain two basic groups of synthetic organic compounds: polycyclic aromatic hydrocarbons and halogenated hydrocarbons, which include several organochlorines (OCs), namely dioxin, furan, polychlorinated biphenyls (PCBs), Mirex, toxaphene, heptachlor, chlordane, and dichloro-diphenyl-trichloroethane (DDT). Historically, halogenated hydrocarbons have been shown to be the most resistant to degradation by photodegradation or heat, and halogenated 
hydrocarbons possess low solubility in water, high solubility in lipids, and are global produced, used, and released. OCs are typically the most persistent of all halogenated hydrocarbons. Universally, the more highly chlorinated biphenyls tend to accumulate to a greater extent than the less chlorinated PCBs; likewise, metabolism and excretion are slower for the highly chlorinated biphenyls than for the less chlorinated PCBs. Polychlorinated dibenzo-p-dioxins (PCDDs) and polychlorinated dibenzofurans (PCDFs) are polyhalogenated aromatic hydrocarbons that exert high toxicity. There are 210 different congeners, including 75 dioxin congeners and 135 furan congeners, of which 17 are potentially toxic. PCBs are a family of 209 congeners for which there are no known natural sources [2].

These substances accumulate with the highest concentration in humans, a top species in the food chain, while remaining in the soil or water and exhibiting toxicity for many years [3]. In May 2001, 12 POP species (aldrin, chlordane, DDT, dieldrin, endrin, heptachlor, hexachlorobenzene (HCB), Mirex, toxaphene, PCBs, PCDDs, and PCDFs) were initially prohibited for use through the Stockholm Convention. Thereafter, nine additional POPs were prohibited in May 2009 [4].

Generally, POPs not only have long half-lives, persisting in the environment for years or decades, but also are widely dispersed around the world, through the air, water currents, and living organisms. Additionally, POPs bioaccumulate and biomagnify, penetrating the food chain; in other words, they bioconcentrate at higher levels in food webs, thus polluting and exposing all living things, including humans. POPs are linked with serious health risks in humans and other living organisms [5]. Since most POPs are lipophilic, they tend to remain in fat-rich tissues, such as adipose tissues.

POPs have been measured in various living organisms [6]. POPs have been measured in biological samples, such as human blood, body fat, and breast milk in studies around the world. These chemicals are not well metabolized or excreted. Thus, even small doses that are ingested daily can accumulate to yield detectable amounts over time [3].

\section{Human Implications of POPs}

The awareness of POPs was the result of large-scale casualties caused by the exposure to high concentrations of POPs in the early 20th century. From 1956 to 1961, more than 4000 cases of porphyria occurred in Eastern Turkey due to the ingestion of HCB [7]. In 1968 and 1979, Japan and Taiwan, respectively, consumed approximately 1200 types of contaminated cooking oil, resulting in "Yusho" (oil disease), which includes symptoms, such as reproductive dysfunction, severe chloracne, hyperpigmentation, discharge from eye, headaches, vomiting, fever, visual disturbances, and respiratory problems. Between 1962 and 1971, there was a strong positive relationship between developmental soft tissue sarcoma, non-Hodgkin's lymphoma, Hodgkin's disease, chloracne, and chronic lymphocytic leukemia, and the use of Agent Orange including 2,3,7,8-tetrachlorodibenzo-p-dioxin (TCDD) [8]. It has also been reported that diabetes mellitus (DM) type 2, hypertension, heart disease, and chronic respiratory conditions are associated with POP exposure [9].

Likewise, POPs are toxic at high levels as demonstrated by mass poisoning incidents. Exposure to high levels of POPs is associated with serious human health problems including death, disease, and birth defects among humans and animals [10]. Specific health risks can include cancer, allergies, hypersensitivity, and damage to the immune, neurological, and reproductive systems.

Initially, it was difficult to reveal the causal relationship between the effects of chronic POPs exposure at very low concentrations compared with high concentrations of acute toxicity, which was revealed much later. According to State of the Science of Endocrine Disrupting Chemicals-2012 published by the WHO in 2012 [1], chronic exposure of lower concentrations of POPs has been shown to lead to female reproductive dysfunction [11,12], testicular cancer [13,14], breast cancer [15], prostate cancer [16], decreased semen quality [17-19], increased cryptorchidism and hypospadias at birth [20,21], and cognitive and behavioral deficits caused by developmental exposure [22-24]. In particular, these neurodevelopmental disorders have been linked to severe forms of thyroid hormone deficiencies, and the decrease of thyroid function has been associated with PCBs, PBDEs, phthalates, 
bisphenol A, and perfluorinated chemicals in some epidemiological studies [25]. Thyroid cancer has also been to have a weak association with pesticides and 2,3,7,8-tetrachlorodibenzo-p-dioxin. With regard to metabolic disorders, decreased bone mineral density or increased risk of bone fractures, obesity, DM type 2, and metabolic syndrome due to the disruption of the energy storage-energy balance endocrine system are suspected to be potentially sensitive to endocrine-disrupting chemicals (EDCs) [26-29].

OCs, PCBs, HCB, and pesticides, including DDT and lindane (g-hexachlorocyclohexane, HCH), are classified as latent carcinogens to humans according to the International Agency for Research on Cancer [30,31]. Regarding the mechanism of cancer development by POPs, an epigenetic mechanism (i.e., chromosomal instability, abnormal gene expression, and DNA methylation) has been suggested, and the inverse relationship between DNA global methylation levels and blood plasma levels for several POPs has been reported [32]. Furthermore, there are strong epidemiological research data associating the exposure to phthalates with airway disorders, including asthma, and the exposure to phthalates and dioxins is associated with endometriosis and allergies.

PCBs that are intensively being released into the environment are also carcinogenic in nature, because they are weakly estrogenic, and some OCs have been tested almost exclusively in epidemiological studies in breast [33,34], prostate [34], colorectal, and endometrial cancers [35], and in non-Hodgkin's lymphoma [36]. Furthermore, the neurotoxic of effects of PCBs are related to dose-response and structure-activity relationships (SAR). Sufficient epidemiological and experimental evidence has shown that PCB exposure is associated with motor and cognitive deficits in humans and animal models [37].

\section{POPs as ECDs}

Endocrine-disrupting chemicals (EDCs) disturb the immune, reproductive, and nervous system in humans and animals. Several studies have previously indicated that POPs are ECDs [38,39]. Recently, many epidemiological studies have provided evidence regarding the relationship between POPs and metabolic disorders. Lee et al. revealed that the levels of Methanobacteriales in the human gut were associated with higher body weight and waist circumference [40]. Janesick et al. suggested the EDCs as an obesogene [41]. The epidemiologic evidences for association between DM type 2 and EDCs were little by little accumulated recently [42-46]. Although rare, the causality of DM type 1 by EDCs also reported [47]. Metabolic syndrome (which is defined clinically as hypertension, abdominal (central) adiposity, increased serum triglycerides, low serum high density lipoproteins (HDL), and high blood sugar, even after fasting [48]) is an important disease group that can cause obesity and DM type 2 [49]. Although several studies also reported the progression of the metabolic syndrome, obesity, and DM type 2 by EDCs [50-52], experimental data revealing the mechanism underlying POPs exposure-induced endocrine disruption are lacking.

An elaborate study revealed that PCB-77 may contribute to the development of obesity and obesity-associated atherosclerosis [53]. The study that examined the in vitro and in vivo effects of PCB-77 and TCDD demonstrated that low concentrations of PCB-77 or TCDD increased adipocyte differentiation, glycerol-3-phosphate dehydrogenase activity, and the expression of peroxisome proliferator-activated receptor gamma. In addition, PCB-77 was shown to promote the expression and release of various proinflammatory cytokines in vitro, and PCB-77 resulted in an increase in body weight, adipocyte hypertrophy, serum dyslipidemia, and augmented atherosclerosis in vivo. However, this study did not address insulin resistance.

\section{Epidemiologic Evidence of POP-Induced Insulin Resistance}

The relationship between POPs and DM type 2 or insulin resistance was not an important issue in the early 20th century, although it has been suggested for people who were constantly and chronically exposed to low concentrations of POPs in the 1990s. The studies regarding exposure to POPs, including TCDD, which is the most potent congener of dioxin, or other POPs in occupational 
or accidental settings, have reported an increased risk of DM type 2, modified glucose metabolism, and insulin resistance [54-58].

The issue of the fully encompassing problem has been reported as a strong relationship between the serum concentration of six POPs $(2,2,4,4,5,5-$ hexachlorobiphenyl, 1,2,3,4,6,7,8-heptachlorodibenzo-p-dioxin, 1,2,3,4,6,7,8,9-octachlorodibenzo-p-dioxin, oxychlordane, $\mathrm{p}, \mathrm{p}$-dichlorodiphenyltrichloroethane, and trans-nonachlor) and the prevalence of DM type 2 [46]. This cross-sectional prospective study involved 2,016 adult participants, and the association was strong despite the adjustment of several confounding factors and stratified analyses, and OCs or nondioxin-like PCB (PCB-153) were found to be most strongly correlated with DM type 2 notably. Furthermore, these authors investigated the relationship between serum concentrations of POPs, especially OC pesticides or nondioxin-like PCBs, and insulin resistance, pre-stage diabetes mellitus, or the potential risk of DM type 2 in nondiabetic adults [59]. This study also showed the association between POPs and insulin resistance, and the authors even suggested the possibility of interaction with obesity to increase the risk of DM type 2. Although the sample size was small, a case-control study has also been reported. For 50 nondiabetic subjects with metabolic syndrome and 50 normal controls, the association between eight $\mathrm{OC}$ pesticides and metabolic syndrome was examined and only heptachlor epoxide was related meaningfully [60].

Beyond the simple examination of the association between POPs and DM type 2, the predictive potential of the occurrence of DM type 2 from POP levels in serum has been examined. Lee et al. measured the serum levels of 8 OC pesticides, 22 PCB congeners, and 1 polybrominated biphenyl (PBB) of 90 controls subjected that remained free of DM type 2. The 90 cases developed DM type 2 in 1987 1988 and in 2005 2006. Although the serum levels of POPs were very low, these levels were very similar to exposure levels observed in nature which increased the risk of DM type 2, suggesting an important role for POPs in current trends in DM type 2 due to obesity [61].

Recently, a toxicology program workshop thoroughly reviewed 72 published epidemiological studies that investigated the associations of POPs with DM type 2 prior to the assessment [62]. According to the review, the association between DM type 2 and OC compounds such as trans-nonachlor, dichlorodiphenyldichloroethylene (DDE), PCBs, dioxins, and dioxin-like chemicals were found to be strongly correlated; however, associations between other non-OC POPs, such as perfluoroalkyl acids and brominated compounds, and DM type 2 were found to be less correlated. However, as the review study also indicated, further experimental data are required to support the epidemiological studies.

\section{Current Concepts Regarding the Mechanism Underlying Insulin Resistance}

Insulin resistance can occur through dysfunction of insulin signaling pathway. Current concepts of insulin signaling pathways are depicted in Figure 1.

\subsection{Mechanism of Insulin Resistance}

Insulin resistance, a condition where cellular responses to insulin are unsuitable, is found primarily in insulin-sensitive tissues, liver, muscle and fat. Insulin resistance can result from various situations including abnormal insulin signaling, lipotoxicity, inflammation, mitochondrial dysfunction, and endoplasmic reticulum (ER) stress. These mechanisms are chiefly mediated by inhibitory serine/threonine phosphorylation, dephosphorylation, transcriptional modifications, posttranslational modifications, and genetic mutations [63]. 


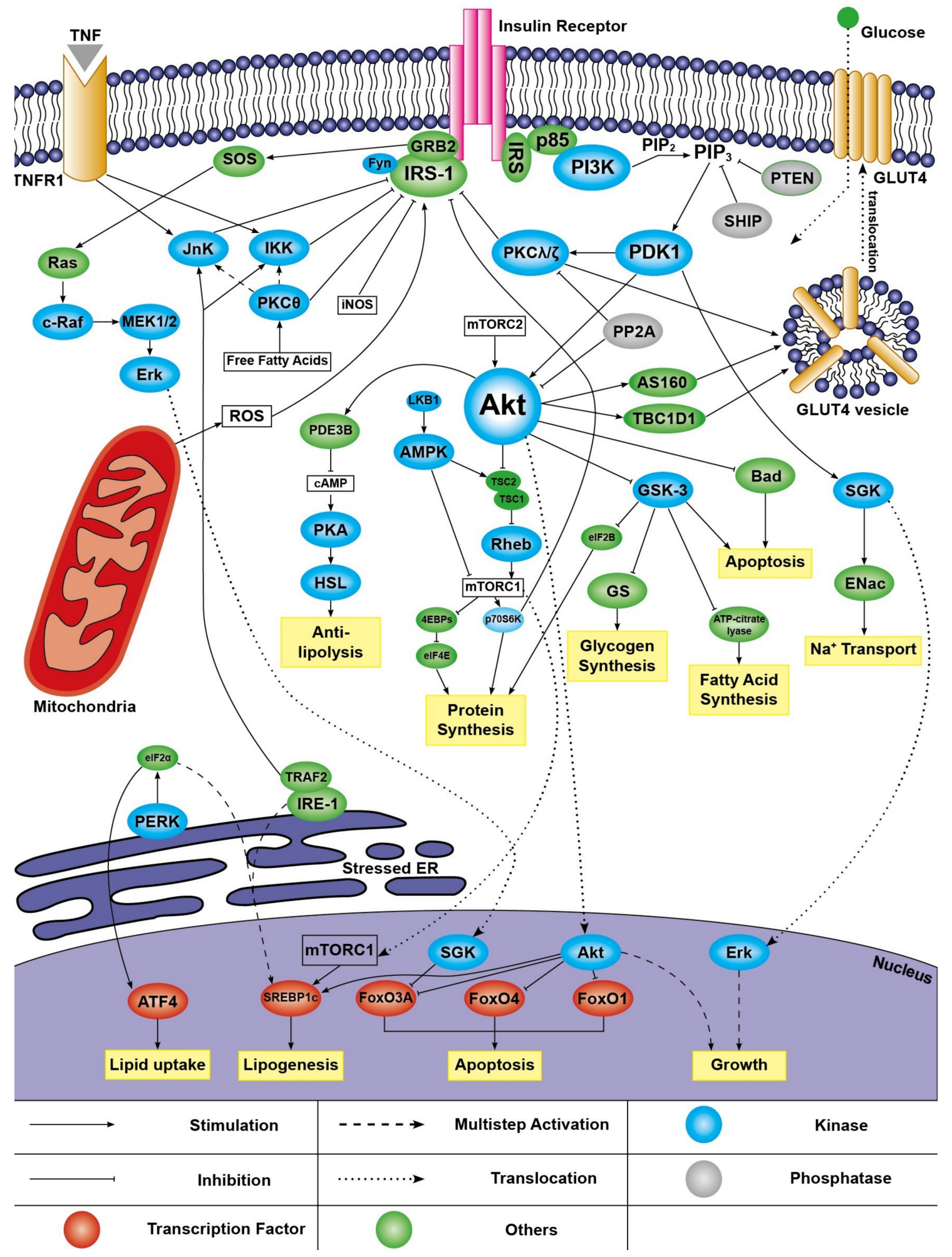

Figure 1. Current concepts of insulin signaling pathways.

\subsection{Insulin Receptor}

Insulin signaling is initiated through insulin binding with the extracellular domains of the insulin receptor, followed by receptor autophosphorylation of several tyrosine residues located in intracellular domains. This tyrosine residue interacts with various adaptor proteins, including insulin receptor substrate-1 and -2 (IRS-1 and IRS-2, respectively) and SH2 domain-containing protein (SHC), 
which bind to intracellular receptor sites and become phosphorylated. Mutations on the insulin receptor have been identified in several conditions such as leprechaunism, Rabson-Mendenhall syndrome, or the type-A syndrome of insulin resistance, but have not been observed in patients with typical DM type 2 [63].

\subsection{IRS Protein}

IRS-1 and IRS-2 recruit the formation of molecular complexes and activate downstream signaling cascades. For example, in IRS-1-deficient mice, insulin resistance develops mainly due to decreased insulin-stimulated glucose metabolism in the muscle alone. In IRS-2-deficient mice, however, multiple defects impact the liver, muscle and adipose tissue, which includes reduced peripheral glucose utilization, reduced suppression of endogenous glucose production, and reduced hepatic glycogen synthesis [64].

\subsection{PI 3-kinase/Akt Signaling}

The key target of the IRS protein is phosphoinositide 3-kinase (PI 3-kinase). PI3-kinase activates phosphoinositide-dependent kinase-1 (PDK1 and PDK2) by the phosphorylation of phosphatidylinositol 4,5 bisphosphate (PIP2) into phosphatidylinositol 3,4,5 triphosphate (PIP3) [65]. Activated PDK1 phosphorylates serine/threonine kinases including Akt/protein kinase B (PKB) and atypical protein kinase $\mathrm{C} \lambda$ and $\zeta(\mathrm{PKC} \lambda / \zeta)[66,67]$. Akt kinase plays a central and varying role in biological processes, including cell growth, survival and, metabolism and responses to hormones, growth factors, and cytokines in numerous cell types [68]. In an in vivo study, Akt2-deficient mice showed insulin resistance in the liver, skeletal muscle, and adipose tissue [69,70]. Among three different isoforms of Akt (Akt 1, 2, and 3), Akt2 is chiefly found in insulin-responsive metabolic tissues and is essential for insulin metabolic processes. Insulin-stimulated Akt2 results in the uptake of circulating glucose through GLUT4 translocation from intracellular compartments to the cell membrane, especially in skeletal muscle and adipose tissue [71]. Insulin signaling to Akt in the liver is crucial to the suppression of glucose production and increased lipid synthesis [72,73]. Insulin-Akt signaling inhibits FoxO1 as a transcription factor that enhances the expression of the gluconeogenic enzymes phosphoenolpyruvate carboxykinase (PEPCK) and glucose 6-phosphatase (G6Pase) [74]. Akt phosphorylation also induces the activation of the SREBP1c transcription factor, which leads to de novo lipid synthesis [73].

\subsection{Roles of Lipotoxicity in Insulin Resistance}

The plasma free fatty acid (FFA) level is controlled by insulin. When the FFA level is continuously elevated, it causes lipotoxicity in non-adipose tissues and insulin resistance, and DM type 2 can occur [75]. High levels of plasma FFA induce the activation of c-Jun N-terminal kinase (JNK), IKB kinase (IKK), and PKC and IRS-1 Ser-307 phosphorylation [76]. Among the FFAs, palmitate especially promotes insulin resistance by ER stress, cytokine production, and activating JNK, and NF-KB [77-79]. Diacylglycerol (DAG) and ceramide, which are intermediate metabolites of FFAs, also induce insulin resistance. Increased muscle DAG causes insulin resistance by activating PKC- $\theta$ and IRS-1 Ser-307 phosphorylation [80]. Ceramide activates PKC and JNK, inhibits Akt activation via Akt Thr-34 phosphorylation, and increases the interaction of protein phosphatase 2 (PP2A) with Akt [81-84].

\subsection{Roles of Inflammation in Insulin Resistance}

In obesity, chronic and low-grade inflammation prevails and is involved in the pathogenesis of various chronic diseases. Pro-inflammatory cytokines secreted in the adipose tissue and by macrophages such as tumor necrosis factor alpha (TNF- $\alpha$ ), interleukin- $1 \beta$ (IL- $1 \beta)$, and IL- 6 can promote insulin resistance by multiple mechanisms $[85,86]$, which include Ser/Thr kinase activation and decreases in IRS-1, glucose transporter type 4 (GLUT-4), and peroxisome proliferator-activated receptor gamma (PPAR $\gamma$ ) expression or suppressor of cytokine signaling 3 (SOCS-3) activation [63,87-89]. 
The activation of Toll-like receptors (TLRs), especially TLR-2 and TLR-4, is also an important factor in inflammation-associated insulin resistance $[78,90]$.

\subsection{Roles of Mitochondrial Dysfunction in Insulin Resistance}

The level of reactive oxygen species (ROS) as a byproduct of the electron transport chain in mitochondria is increased as a result of insulin resistance [91]. Increased ROS levels can be caused by reduced antioxidant enzymes, and alterations in mitochondrial proteins [92,93]. Increased ROS levels activate the phosphorylation of the insulin receptor and the insulin receptor substrate and decrease the level of the FoxO1 transcriptional factor, which eventually results in insulin resistance $[93,94]$. Because FFA metabolism is chiefly mediated by mitochondria, a decrease in mitochondrial function can lead to FFA and lipid accumulation and subsequent insulin resistance.

\subsection{Roles of ER Stress in Insulin Resistance}

The endoplasmic reticulum (ER) has many functions including protein folding, posttranslational modifications, and calcium storage. Some physiological conditions that increase the demand for protein folding or the stimuli that disrupt protein folding, result in the accumulation of unfolded or misfolded proteins in the ER lumen [95]. For re-establishing the protein-folding capacity and preventing the accumulation of unfolded or misfolded proteins, a mechanism known as the unfolding protein response (UPR) is activated by the alteration of transcriptional and translational processes [95]. Three ER membrane-associated proteins, which include PKR-like eukaryotic initiation factor $2 \alpha$ kinase (PERK), inositol requiring enzyme1 (IRE1), and activating transcription factor-6 (ATF6), are known as ER membrane-associated proteins to be related to the UPR and activate inflammatory pathways, such as TNF- $\alpha$, IL-1 $\beta$, and IL-6 by nuclear factor kappa-light-chain-enhancer of activated B cells (NF-kB) activation and finally result in insulin resistance [96]. In the case of IRE kinase, the phosphorylation of IRE- $1 \alpha$ recruits the tumor necrosis factor receptor-associated factor 2 (TRAF2) protein, which activates JNK and subsequent IRS-1 phosphorylation [79].

\section{Experimental Animal Studies Investigating the Mechanism Underlying POP-Induced Insulin Resistance}

Several previous experimental studies have provided evidence supporting the association between POPs exposure and DM type 2 or insulin resistance [97-100]. Ruzzin et al. demonstrated that chronic exposure to low doses of a POP mixture, which is commonly found in food chains, induced the severe impairment of whole-body insulin activity and contributed to the development of abdominal obesity in rats. The in vitro treatment of differentiated adipocytes with nanomolar concentrations of POPs mixtures, which mimic those found in crude salmon oil, induced a significant inhibition of insulin-dependent glucose uptake [97]. A causal relationship between POPs and insulin resistance was demonstrated by subsequent studies. Ibrahim et al. elucidated that the chronic consumption of farmed salmon containing POPs causes insulin resistance and obesity in mice [100]. Gray et al. also provided evidence supporting that chronic exposure to PCBs (Aroclor 1254) exacerbates obesity-induced insulin resistance and hyperinsulinemia in mice [99]. Lv et al. studied the consequences of gestational and lactational exposure to a POP perfluorooctane sulfonate (PFOS) on the effects of pre-DM in offspring. In the study, they demonstrated that glucose and lipid homeostasis in adult rats is impaired by early-life exposure to PFOS [98]. These experimental studies provide compelling evidence that exposure to POPs increases the risk of developing insulin resistance and metabolic disorders. However, to date, the detailed molecular mechanism underlying POP-induced insulin resistance is yet to be elucidated.

The lack of information on the molecular aspects of POP-induced insulin resistance might primarily be a result of the lack of interest in this issue by contemporary life scientists who focus on cell and molecular biology. Difficult experimental approaches might also limit further study. Although epidemiological findings suggest an association between low-level chronic exposure to certain POPs and disease outcomes, the chronic exposure to POPs at low doses requires a long period 
of time to investigate. Therefore, many studies have investigated single POP treatments for a short duration. Thus, it is not completely clear that the data obtained from these experimental systems are relevant to human exposure. However, the exposure to multiple contaminants found in the environment could produce increased adverse effects by synergistic toxicity mechanisms, resulting in the lack of information [101].

Despite this limitation, numerous experimental studies have provided data supporting the association between POPs exposure and DM type 2. Experimental studies reporting that POPs alter glucose transport activity [102-105] and that POPs increase adiposity $[85,106,107]$ have provided insight regarding the mechanism underlying POP-induced insulin resistance because increased adiposity as well as altered glucose transport activity are associated with insulin resistance. However, these studies did not reveal the detailed mechanism by which POPs alter insulin signaling. An experimental study has shown that chronic consumption of salmon containing POPs impairs the ability of insulin to stimulate Akt phosphorylation in vivo. Another study has shown that PCB-153 impairs insulin sensitivity through the dysregulation of hepatocyte nuclear factor $1 \mathrm{~b}$ (HNF1b)/ROS/NF-KB [108]. Recently, we revealed the mechanism underlying the insulin resistance induced by PCB-118 and PCB-138 [109]. In that study, we demonstrated that PCB-118 or PCB-138 promotes large lipid droplet (LD) formation through fat-specific protein 27 (Fsp27). In addition, we elucidated that PCB-118 or PCB-138 impair the insulin-induced upregulation of p-Akt (Ser473) and p-PI3K p85 (Tyr458). Importantly, we elicited that Fsp27 mediates PCB-induced insulin resistance via IRS1 downregulation [109]. In another study, we demonstrated the mechanism underlying the obesity induced by PCB-138. In that study, we elucidated that LD enlargement induced by PCB-138 confers adipocytes the resistance to TNF- $\alpha$-induced cell death. In addition, we elicited that Fsp27, perilipin, and survivin, at least in part, are involved in sustaining enlarged LDs, which contributes to the induction of obesity and subsequent insulin resistance [110].

\section{Future Tasks}

According to previous epidemiological studies, the overall evidence is sufficient for a positive association of some OC POPs with DM type 2. However, further experimental data are needed to confirm the causality of these POPs. Dynamic experimental studies might not only prove the causality but also provide important insights into the pathogenesis of DM type 2 and the mechanisms governing POP-mediated insulin resistance. Experimental studies could offer a suitable target for interventions targeting PCB-induced insulin resistance. For example, a previous study demonstrated that PCB-induced impairment of glucose homeostasis in mice can be prevented by resveratrol, potentially through the stimulation of Nrf2 signaling and enhanced insulin-stimulated glucose disposal in adipose tissue [111]. In a previous study, we showed that the depletion of the Fsp27 gene resulted in the inhibition of LD enlargement and attenuation of insulin resistance [109]. Furthermore, we demonstrated that metformin, a representative insulin resistance-improving drug, alleviates PCBs-induced insulin resistance through Fsp27. These reports, in conjunction with future studies, could provide us with an avenue for interventions targeting PCBs-induced insulin resistance.

\section{Conclusions}

Numerous epidemiological studies have provided compelling evidence indicating that exposure to POPs increases the risk of developing insulin resistance and metabolic disorders. Several experimental studies have provided evidence supporting the association between POP exposure and DM type 2 or insulin resistance. However, the detailed molecular mechanism underlying POP-induced insulin resistance is yet to be elucidated. Despite these limitations of experimental approaches, experimental studies which have been recently reported provided new insight regarding the pathogenesis of DM type 2. Experimental studies could offer a suitable target for interventions targeting PCB-induced insulin resistance. 
Moreover, new information obtained from experimental studies could be considered by governing organizations that are involved in the regulation of environmental contaminants.

Author Contributions: Wrote or contributed to the writing of the manuscript: Y.A.K., J.B.P., M.S.W., S.Y.L., H.Y.K., and Y.H.Y.; Funding Acquisition: Y.H.Y.

Funding: This study was supported by the National Research Foundation of Korea (NRF) grant funded by the Korean Government (MIST) (No. 2015R1A2A1A10051603, 2016R1A5A2007009, and 2016R1C1B2011721).

Conflicts of Interest: The authors declare that they have no conflicts of interest.

\section{References}

1. World Health Organization. State of the Science of Endocrine Disrupting Chemicals-2012; World Health Organization: Geneva, Switzerland, 2017.

2. Ritter, L.; Solomon, K.; Forget, J.; Stemeroff, M.; O'leary, C. A Review of Selected Persistent Organic Pollutants; International Programme on Chemical Safety (IPCS). PCS/95.39; World Health Organization: Geneva, Switzerland, 1995; Volume 65, p. 66.

3. Geyer, H.J.; Rimkus, G.G.; Scheunert, I.; Kaune, A.; Schramm, K.; Kettrup, A.; Zeeman, M.; Muir, D.C.; Hansen, L.G.; Mackay, D. Bioaccumulation and occurrence of endocrine-disrupting chemicals (EDCs), persistent organic pollutants (POPs), and other organic compounds in fish and other organisms including humans. In Bioaccumulation-New Aspects and Developments 2000; Springer: Berlin/Heidelberg, Germany; pp. 1-166.

4. Lallas, P.L. The Stockholm Convention on Persistent Organic Pollutants. Am. J. Int. Law 2001, 95, 692-708. [CrossRef]

5. World Health Organization. Persistent Organic Pollutants: Impact on Child Health; World Health Organization: Geneva, Switzerland, 2010.

6. Li, Q.Q.; Loganath, A.; Chong, Y.S.; Tan, J.; Obbard, J.P. Persistent Organic Pollutants and Adverse Health Effects in Humans. J. Toxicol. Environ. Health Part A 2006, 69, 1987-2005. [PubMed]

7. Cripps, D.J.; Gocmen, A.; Peters, H.A. Porphyria Turcica: Twenty Years After Hexachlorobenzene Intoxication. Arch. Dermatol. 1980, 116, 46-50. [CrossRef] [PubMed]

8. Schecter, A.; Dai, L.C.; Thuy, L.T.; Quynh, H.T.; Minh, D.Q.; Cau, H.D.; Phiet, P.H.; Nguyen, N.T.; Constable, J.D.; Baughman, R. Agent Orange and the Vietnamese: The Persistence of Elevated Dioxin Levels in Human Tissues. Am. J. Public Health 1995, 85, 516-522. [CrossRef] [PubMed]

9. Kang, H.K.; Dalager, N.A.; Needham, L.L.; Patterson, D.G., Jr.; Lees, P.S.; Yates, K.; Matanoski, G.M. Health Status of Army Chemical Corps Vietnam Veterans Who Sprayed Defoliant in Vietnam. Am. J. Ind. Med. 2006, 49, 875-884. [CrossRef] [PubMed]

10. Etzel, R.A.; Balk, S.J. Pediatric Environmental Health, 3rd ed.; American Academy of Pediatrics: Itasca, IL, USA, 2011.

11. Wade, M. Human Health and Exposure to Chemicals Which Disrupt Estrogen, Androgen and Thyroid Hormone Physiology; Health Canada: Ottawa, ON, Canada, 1999.

12. Sharpe, R.M.; Irvine, D.S. How Strong is the Evidence of a Link between Environmental Chemicals and Adverse Effects on Human Reproductive Health? BMJ 2004, 328, 447-451. [CrossRef] [PubMed]

13. Boisen, K.; Kaleva, M.; Main, K.; Virtanen, H.; Haavisto, A.; Schmidt, I.; Chellakooty, M.; Damgaard, I.; Mau, C.; Reunanen, M. Difference in Prevalence of Congenital Cryptorchidism in Infants between Two Nordic Countries. Lancet 2004, 363, 1264-1269. [CrossRef]

14. Jacobsen, R.; MØller, H.; Thoresen, S.Ø.; Pukkala, E.; Kjaer, S.K.; Johansen, C. Trends in Testicular Cancer Incidence in the Nordic Countries, Focusing on the Recent Decrease in Denmark. Int. J. Androl. 2006, 29, 199-204. [CrossRef]

15. Krieger, N.; Wolff, M.S.; Hiatt, R.A.; Rivera, M.; Vogelman, J.; Orentreich, N. Breast Cancer and Serum Organochlorines: A Prospective Study among White, Black, and Asian Women. J. Natl. Cancer Inst. 1994, 86, 589-599. [CrossRef]

16. Hardell, L.; Andersson, S.; Carlberg, M.; Bohr, L.; van Bavel, B.; Lindström, G.; Björnfoth, H.; Ginman, C. Adipose Tissue Concentrations of Persistent Organic Pollutants and the Risk of Prostate Cancer. J. Occup. Environ. Med. 2006, 48, 700-707. [CrossRef] 
17. Lee, P.A.; Coughlin, M.T. Fertility After Bilateral Cryptorchidism. Evaluation by Paternity, Hormone, and Semen Data. Horm. Res. 2001, 55, 28-32.

18. Foster, P.M. Mode of Action: Impaired Fetal Leydig Cell Function-Effects on Male Reproductive Development Produced by Certain Phthalate Esters. Crit. Rev. Toxicol. 2005, 35, 713-719. [CrossRef] [PubMed]

19. Foster, P.M. Disruption of Reproductive Development in Male Rat Offspring Following in Utero Exposure to Phthalate Esters. Int. J. Androl. 2006, 29, 140-147. [CrossRef] [PubMed]

20. Aneck-Hahn, N.H.; Schulenburg, G.W.; Bornman, M.S.; Farias, P.; De Jager, C. Impaired Semen Quality Associated with Environmental DDT Exposure in Young Men Living in a Malaria Area in the Limpopo Province, South Africa. J. Androl. 2007, 28, 423-434. [CrossRef] [PubMed]

21. Bhatia, R.; Shiau, R.; Petreas, M.; Weintraub, J.M.; Farhang, L.; Eskenazi, B. Organochlorine Pesticides and Male Genital Anomalies in the Child Health and Development Studies. Environ. Health Perspect. 2005, 113, 220-224. [CrossRef] [PubMed]

22. Lai, T.; Guo, Y.; Yu, M.; Ko, H.; Hsu, C. Cognitive Development in Yucheng Children. Chemosphere 1994, 29, 2405-2411. [CrossRef]

23. Lai, T.; Guo, Y.; Guo, N.; Hsu, C. Effect of Prenatal Exposure to Polychlorinated Biphenyls on Cognitive Development in Children: A Longitudinal Study in Taiwan. Br. J. Psychiatry 2001, 178, S49-S52. [CrossRef]

24. Ribas-Fito, N.; Sala, M.; Kogevinas, M.; Sunyer, J. Polychlorinated Biphenyls (PCBs) and Neurological Development in Children: A Systematic Review. J. Epidemiol. Community Health 2001, 55, 537-546. [CrossRef]

25. Brouwer, A.; Morse, D.C.; Lans, M.C.; Gerlienke Schuur, A.; Murk, A.J.; Klasson-Wehler, E.; Bergman, Å.; Visser, T.J. Interactions of Persistent Environmental Organohalogens with the Thyroid Hormone System: Mechanisms and Possible Consequences for Animal and Human Health. Toxicol. Ind. Health 1998, 14, 59-84. [CrossRef]

26. Wingren, G.; Hallquist, A.; Degerman, A.; Hardell, L. Occupation and Female Papillary Cancer of the Thyroid. J. Occup. Environ. Med. 1995, 37, 294-297. [CrossRef]

27. Lee, W.J.; Blair, A.; Hoppin, J.A.; Lubin, J.H.; Rusiecki, J.A.; Sandler, D.P.; Dosemeci, M.; Alavanja, M.C. Cancer Incidence among Pesticide Applicators Exposed to Chlorpyrifos in the Agricultural Health Study. J. Natl. Cancer Inst. 2004, 96, 1781-1789. [CrossRef]

28. Lope, V.; Pollán, M.; Gustavsson, P.; Plato, N.; Pérez-Gómez, B.; Aragonés, N.; Suárez, B.; Carrasco, J.M.; Rodríguez, S.; Ramis, R. Occupation and Thyroid Cancer Risk in Sweden. J. Occup. Environ. Med. 2005, 47, 948-957. [CrossRef] [PubMed]

29. Blair, A.; Sandler, D.; Thomas, K.; Hoppin, J.A.; Kamel, F.; Coble, J.; Lee, W.J.; Rusiecki, J.; Knott, C.; Dosemeci, M. Disease and Injury among Participants in the Agricultural Health Study. J. Agric. Saf. Health 2005, 11, 141-150. [CrossRef] [PubMed]

30. International Agency for Research on Cancer. Overall Evaluations of Carcinogenicity: And Updating of IARC Monographs, Vol. 1 to 42. IARC Monographs on the Evaluation of the Carcinogenic Risk of Chemicals to Humans: Suppl 7; IARC: Lyon, France, 1987; Volume 7, pp. 1-440.

31. IARC Working Group on the Evaluation of Carcinogenic Risks to Humans. Occupational Exposures in Insecticide Application, and some Pesticides; World Health Organization: Geneva, Switzerland, 1991.

32. Rusiecki, J.A.; Baccarelli, A.; Bollati, V.; Tarantini, L.; Moore, L.E.; Bonefeld-Jorgensen, E.C. Global DNA Hypomethylation is Associated with High Serum-Persistent Organic Pollutants in Greenlandic Inuit. Environ. Health Perspect. 2008, 116, 1547-1552. [CrossRef] [PubMed]

33. Aronson, K.J.; Miller, A.B.; Woolcott, C.G.; Sterns, E.E.; McCready, D.R.; Lickley, L.A.; Fish, E.B.; Hiraki, G.Y.; Holloway, C.; Ross, T.; et al. Breast Adipose Tissue Concentrations of Polychlorinated Biphenyls and Other Organochlorines and Breast Cancer Risk. Cancer Epidemiol. Biomark. Prev. 2000, 9, 55-63.

34. Høyer, A.P.; Jørgensen, T.; Rank, F.; Grandjean, P. Organochlorine Exposures Influence on Breast Cancer Risk and Survival According to Estrogen Receptor Status: A Danish Cohort-Nested Case-Control Study. BMC Cancer 2001, 1, 8. [CrossRef]

35. Howsam, M.; Grimalt, J.O.; Guino, E.; Navarro, M.; Marti-Rague, J.; Peinado, M.A.; Capella, G.; Moreno, V.; Bellvitge Colorectal Cancer Group. Organochlorine Exposure and Colorectal Cancer Risk. Environ. Health Perspect. 2004, 112, 1460-1466. [CrossRef] [PubMed] 
36. Quintana, P.J.; Delfino, R.J.; Korrick, S.; Ziogas, A.; Kutz, F.W.; Jones, E.L.; Laden, F.; Garshick, E. Adipose Tissue Levels of Organochlorine Pesticides and Polychlorinated Biphenyls and Risk of Non-Hodgkin's Lymphoma. Environ. Health Perspect. 2004, 112, 854-861. [CrossRef]

37. Kodavanti, P.R.S. Neurotoxicity of Persistent Organic Pollutants: Possible Mode (s) of Action and further Considerations. Dose-Response 2005, 3, 273-305. [CrossRef]

38. Kortenkamp, A.; Martin, O.; Faust, M.; Evans, R.; McKinlay, R.; Orton, F.; Rosivatz, E. State of the Art Assessment of Endocrine Disrupters; UNEP: Nairobi, Kenya, 2009.

39. Diamanti-Kandarakis, E.; Bourguignon, J.; Giudice, L.C.; Hauser, R.; Prins, G.S.; Soto, A.M.; Zoeller, R.T.; Gore, A.C. Endocrine-Disrupting Chemicals: An Endocrine Society Scientific Statement. Endocr. Rev. 2009, 30, 293-342. [CrossRef]

40. Lee, H.; Lee, J.; Lee, I.; Moon, H.; Chang, Y.; Jacobs, D.R., Jr.; Lee, D. Associations among Organochlorine Pesticides, Methanobacteriales, and Obesity in Korean Women. PLOS ONE 2011, 6, e27773. [CrossRef]

41. Janesick, A.; Blumberg, B. Endocrine Disrupting Chemicals and the Developmental Programming of Adipogenesis and Obesity. Birth Defects Res. Part C 2011, 93, 34-50. [CrossRef] [PubMed]

42. Neel, B.A.; Sargis, R.M. The Paradox of Progress: Environmental Disruption of Metabolism and the Diabetes Epidemic. Diabetes 2011, 60, 1838-1848. [CrossRef] [PubMed]

43. Everett, C.J.; Frithsen, I.; Player, M. Relationship of Polychlorinated Biphenyls with Type 2 Diabetes and Hypertension. J. Environ. Monit. 2011, 13, 241-251. [CrossRef] [PubMed]

44. Reilly, R.E.; Cincotta, M.; Doyle, J.; Firebrace, B.R.; Cargo, M.; Van den Tol, G.; Morgan-Bulled, D.; Rowley, K.G. A Pilot Study of Aboriginal Health Promotion from an Ecological Perspective. BMC Public Health 2011, 11, 749. [CrossRef] [PubMed]

45. World Health Organization. DDT in Indoor Residual Spraying: Human Health Aspects; World Health Organization: Geneva, Switzerland, 2011.

46. Lee, D.H.; Lee, I.K.; Song, K.; Steffes, M.; Toscano, W.; Baker, B.A.; Jacobs, D.R., Jr. A Strong Dose-Response Relation between Serum Concentrations of Persistent Organic Pollutants and Diabetes: Results from the National Health and Examination Survey 1999-2002. Diabetes Care 2006, 29, 1638-1644. [CrossRef] [PubMed]

47. Howard, S.G.; Lee, D.H. What is the Role of Human Contamination by Environmental Chemicals in the Development of Type 1 Diabetes? J. Epidemiol. Community Health 2012, 66, 479-481. [CrossRef] [PubMed]

48. Steinbeck, K. Insulin resistance syndrome in children and adolescents: Clinical meaning and indication for action. Int. J. Obes. Relat. Metab. Disord. 2004, 28, 829-832. [CrossRef] [PubMed]

49. Abrams, P.; Katz, L.E.L. Metabolic Effects of Obesity Causing Disease in Childhood. Curr. Opin. Endocrinol. Diabetes Obes. 2011, 18, 23-27. [CrossRef]

50. Newbold, R.R. Impact of Environmental Endocrine Disrupting Chemicals on the Development of Obesity. Hormones 2010, 9, 206-217. [CrossRef]

51. La Merrill, M.; Birnbaum, L.S. Childhood Obesity and Environmental Chemicals. Mt. Sinai J. Med. 2011, 78, 22-48. [CrossRef]

52. Tang-Péronard, J.L.; Andersen, H.R.; Jensen, T.K.; Heitmann, B.L. Endocrine-disrupting Chemicals and Obesity Development in Humans: A Review. Obes. Rev. 2011, 12, 622-636. [CrossRef] [PubMed]

53. Arsenescu, V.; Arsenescu, R.I.; King, V.; Swanson, H.; Cassis, L.A. Polychlorinated Biphenyl-77 Induces Adipocyte Differentiation and Proinflammatory Adipokines and Promotes Obesity and Atherosclerosis. Environ. Health Perspect. 2008, 116, 761-768. [CrossRef] [PubMed]

54. Henriksen, G.L.; Ketchum, N.S.; Michalek, J.E.; Swaby, J.A. Serum Dioxin and Diabetes Mellitus in Veterans of Operation Ranch Hand. Epidemiology 1997, 8, 252-258. [CrossRef] [PubMed]

55. Bertazzi, P.A.; Bernucci, I.; Brambilla, G.; Consonni, D.; Pesatori, A.C. The Seveso Studies on Early and Long-Term Effects of Dioxin Exposure: A Review. Environ. Health Perspect. 1998, 106, 625-633. [PubMed]

56. Vena, J.; Boffetta, P.; Becher, H.; Benn, T.; Bueno-de-Mesquita, H.B.; Coggon, D.; Colin, D.; Flesch-Janys, D.; Green, L.; Kauppinen, T.; et al. Exposure to Dioxin and Nonneoplastic Mortality in the Expanded IARC International Cohort Study of Phenoxy Herbicide and Chlorophenol Production Workers and Sprayers. Environ. Health Perspect. 1998, 106, 645-653.

57. Steenland, K.; Piacitelli, L.; Deddens, J.; Fingerhut, M.; Chang, L.I. Cancer, Heart Disease, and Diabetes in Workers Exposed to 2,3,7,8-Tetrachlorodibenzo-P-Dioxin. J. Natl. Cancer Inst. 1999, 91, 779-786. [CrossRef] [PubMed] 
58. Longnecker, M.P.; Michalek, J.E. Serum Dioxin Level in Relation to Diabetes Mellitus among Air Force Veterans with Background Levels of Exposure. Epidemiology 2000, 11, 44-48. [CrossRef]

59. Lee, D.H.; Lee, I.K.; Jin, S.H.; Steffes, M.; Jacobs, D.R., Jr. Association between Serum Concentrations of Persistent Organic Pollutants and Insulin Resistance among Nondiabetic Adults: Results from the National Health and Nutrition Examination Survey 1999-2002. Diabetes Care 2007, 30, 622-628. [CrossRef]

60. Park, S.K.; Son, H.K.; Lee, S.K.; Kang, J.H.; Chang, Y.S.; Jacobs, D.R.; Lee, D.H. Relationship between Serum Concentrations of Organochlorine Pesticides and Metabolic Syndrome among Non-Diabetic Adults. J. Prev. Med. Public. Health. 2010, 43, 1-8. [CrossRef]

61. Lee, D.; Steffes, M.W.; Sjödin, A.; Jones, R.S.; Needham, L.L.; Jacobs, D.R., Jr. Low Dose of some Persistent Organic Pollutants Predicts Type 2 Diabetes: A Nested Case-Control Study. Environ. Health Perspect. 2010, 118, 1235-1242. [CrossRef]

62. Taylor, K.W.; Novak, R.F.; Anderson, H.A.; Birnbaum, L.S.; Blystone, C.; Devito, M.; Jacobs, D.; Kohrle, J.; Lee, D.H.; Rylander, L.; et al. Evaluation of the Association between Persistent Organic Pollutants (POPs) and Diabetes in Epidemiological Studies: A National Toxicology Program Workshop Review. Environ. Health Perspect. 2013, 121, 774-783. [CrossRef] [PubMed]

63. Boucher, J.; Kleinridders, A.; Kahn, C.R. Insulin Receptor Signaling in Normal and Insulin-Resistant States. Cold Spring Harb. Perspect. Biol. 2014, 6, a009191. [CrossRef] [PubMed]

64. Previs, S.F.; Withers, D.J.; Ren, J.M.; White, M.F.; Shulman, G.I. Contrasting Effects of IRS-1 Versus IRS-2 Gene Disruption on Carbohydrate and Lipid Metabolism in Vivo. J. Biol. Chem. 2000, 275, 38990-38994. [CrossRef] [PubMed]

65. Alessi, D.R.; Cohen, P. Mechanism of Activation and Function of Protein Kinase B. Curr. Opin. Genet. Dev. 1998, 8, 55-62. [CrossRef]

66. Sale, E.M.; Sale, G.J. Protein Kinase B: Signalling Roles and Therapeutic Targeting. Cell. Mol. Life Sci. 2008, 65, 113-127. [CrossRef] [PubMed]

67. Farese, R.V.; Sajan, M.P.; Standaert, M.L. Insulin-Sensitive Protein Kinases (Atypical Protein Kinase C and Protein Kinase B/Akt): Actions and Defects in Obesity and Type II Diabetes. Exp. Biol. Med. 2005, 230, 593-605. [CrossRef]

68. Manning, B.D.; Toker, A. AKT/PKB Signaling: Navigating the Network. Cell 2017, 169, 381-405. [CrossRef]

69. Cho, H.; Mu, J.; Kim, J.K.; Thorvaldsen, J.L.; Chu, Q.; Crenshaw, E.B.; Kaestner, K.H.; Bartolomei, M.S.; Shulman, G.I.; Birnbaum, M.J. Insulin Resistance and a Diabetes Mellitus-Like Syndrome in Mice Lacking the Protein Kinase Akt2 (PKB Beta). Science 2001, 292, 1728-1731. [CrossRef]

70. Garofalo, R.S.; Orena, S.J.; Rafidi, K.; Torchia, A.J.; Stock, J.L.; Hildebrandt, A.L.; Coskran, T.; Black, S.C.; Brees, D.J.; Wicks, J.R.; et al. Severe Diabetes, Age-Dependent Loss of Adipose Tissue, and Mild Growth Deficiency in Mice Lacking Akt2/PKB Beta. J. Clin. Investig. 2003, 112, 197-208. [CrossRef]

71. Calera, M.R.; Martinez, C.; Liu, H.; Jack, A.K.; Birnbaum, M.J.; Pilch, P.F. Insulin Increases the Association of Akt-2 with Glut4-Containing Vesicles. J. Biol. Chem. 1998, 273, 7201-7204. [CrossRef]

72. Ono, H.; Shimano, H.; Katagiri, H.; Yahagi, N.; Sakoda, H.; Onishi, Y.; Anai, M.; Ogihara, T.; Fujishiro, M.; Viana, A.Y.I.; et al. Hepatic Akt Activation Induces Marked Hypoglycemia, Hepatomegaly, and Hypertriglyceridemia with Sterol Regulatory Element Binding Protein Involvement. Diabetes 2003, 52, 2905-2913. [CrossRef]

73. Leavens, K.F.; Easton, R.M.; Shulman, G.I.; Previs, S.F.; Birnbaum, M.J. Akt2 is Required for Hepatic Lipid Accumulation in Models of Insulin Resistance. Cell Metab. 2009, 10, 405-418. [CrossRef] [PubMed]

74. Matsumoto, M.; Pocai, A.; Rossetti, L.; Depinho, R.A.; Accili, D. Impaired Regulation of Hepatic Glucose Production in Mice Lacking the Forkhead Transcription Factor Foxo1 in Liver. Cell Metab. 2007, 6, 208-216. [CrossRef] [PubMed]

75. Paolisso, G.; Tataranni, P.A.; Foley, J.E.; Bogardus, C.; Howard, B.V.; Ravussin, E. A High Concentration of Fasting Plasma Non-Esterified Fatty Acids is a Risk Factor for the Development of NIDDM. Diabetologia 1995, 38, 1213-1217. [CrossRef] [PubMed]

76. Schenk, S.; Saberi, M.; Olefsky, J.M. Insulin Sensitivity: Modulation by Nutrients and Inflammation. J. Clin. Investig. 2008, 118, 2992-3002. [CrossRef] [PubMed]

77. Sinha, S.; Perdomo, G.; Brown, N.F.; O'Doherty, R.M. Fatty Acid-Induced Insulin Resistance in L6 Myotubes is Prevented by Inhibition of Activation and Nuclear Localization of Nuclear Factor Kappa B. J. Biol. Chem. 2004, 279, 41294-41301. [CrossRef] 
78. Shi, H.; Kokoeva, M.V.; Inouye, K.; Tzameli, I.; Yin, H.; Flier, J.S. TLR4 Links Innate Immunity and Fatty Acid-Induced Insulin Resistance. J. Clin. Investig. 2006, 116, 3015-3025. [CrossRef]

79. Ozcan, U.; Cao, Q.; Yilmaz, E.; Lee, A.; Iwakoshi, N.N.; Ozdelen, E.; Tuncman, G.; Gorgun, C.; Glimcher, L.H.; Hotamisligil, G.S. Endoplasmic Reticulum Stress Links Obesity, Insulin Action, and Type 2 Diabetes. Science 2004, 306, 457-461. [CrossRef]

80. Yu, C.; Chen, Y.; Cline, G.W.; Zhang, D.; Zong, H.; Wang, Y.; Bergeron, R.; Kim, J.K.; Cushman, S.W.; Cooney, G.J.; et al. Mechanism by which Fatty Acids Inhibit Insulin Activation of Insulin Receptor Substrate-1 (IRS-1)-Associated Phosphatidylinositol 3-Kinase Activity in Muscle. J. Biol. Chem. 2002, 277, 50230-50236. [CrossRef]

81. Westwick, J.K.; Bielawska, A.E.; Dbaibo, G.; Hannun, Y.A.; Brenner, D.A. Ceramide Activates the Stress-Activated Protein Kinases. J. Biol. Chem. 1995, 270, 22689-22692. [CrossRef]

82. Teruel, T.; Hernandez, R.; Lorenzo, M. Ceramide Mediates Insulin Resistance by Tumor Necrosis Factor-Alpha in Brown Adipocytes by Maintaining Akt in an Inactive Dephosphorylated State. Diabetes 2001, 50, 2563-2571. [CrossRef] [PubMed]

83. Powell, D.J.; Hajduch, E.; Kular, G.; Hundal, H.S. Ceramide Disables 3-Phosphoinositide Binding to the Pleckstrin Homology Domain of Protein Kinase B (PKB)/Akt by a PKCzeta-Dependent Mechanism. Mol. Cell. Biol. 2003, 23, 7794-7808. [CrossRef]

84. Blouin, C.M.; Prado, C.; Takane, K.K.; Lasnier, F.; Garcia-Ocana, A.; Ferre, P.; Dugail, I.; Hajduch, E. Plasma Membrane Subdomain Compartmentalization Contributes to Distinct Mechanisms of Ceramide Action on Insulin Signaling. Diabetes 2010, 59, 600-610. [CrossRef] [PubMed]

85. Hotamisligil, G.S.; Shargill, N.S.; Spiegelman, B.M. Adipose Expression of Tumor Necrosis Factor-Alpha: Direct Role in Obesity-Linked Insulin Resistance. Science 1993, 259, 87-91. [CrossRef] [PubMed]

86. Halberg, N.; Wernstedt-Asterholm, I.; Scherer, P.E. The Adipocyte as an Endocrine Cell. Endocrinol. Metab. Clin. N. Am. 2008, 37, 935-941. [CrossRef] [PubMed]

87. Senn, J.J.; Klover, P.J.; Nowak, I.A.; Zimmers, T.A.; Koniaris, L.G.; Furlanetto, R.W.; Mooney, R.A. Suppressor of Cytokine Signaling-3 (SOCS-3), a Potential Mediator of Interleukin-6-Dependent Insulin Resistance in Hepatocytes. J. Biol. Chem. 2003, 278, 13740-13746. [CrossRef] [PubMed]

88. Plomgaard, P.; Bouzakri, K.; Krogh-Madsen, R.; Mittendorfer, B.; Zierath, J.R.; Pedersen, B.K. Tumor Necrosis Factor-Alpha Induces Skeletal Muscle Insulin Resistance in Healthy Human Subjects Via Inhibition of Akt Substrate 160 Phosphorylation. Diabetes 2005, 54, 2939-2945. [CrossRef]

89. Steppan, C.M.; Wang, J.; Whiteman, E.L.; Birnbaum, M.J.; Lazar, M.A. Activation of SOCS-3 by Resistin. Mol. Cell. Biol. 2005, 25, 1569-1575. [CrossRef]

90. Reyna, S.M.; Ghosh, S.; Tantiwong, P.; Meka, C.S.R.; Eagan, P.; Jenkinson, C.P.; Cersosimo, E.; Defronzo, R.A.; Coletta, D.K.; Sriwijitkamol, A.; et al. Elevated Toll-Like Receptor 4 Expression and Signaling in Muscle from Insulin-Resistant Subjects. Diabetes 2008, 57, 2595-2602. [CrossRef]

91. Hoehn, K.L.; Salmon, A.B.; Hohnen-Behrens, C.; Turner, N.; Hoy, A.J.; Maghzal, G.J.; Stocker, R.; Remmen, H.V.; Kraegen, E.W.; Cooney, G.J.; et al. Insulin Resistance is a Cellular Antioxidant Defense Mechanism. Proc. Natl. Acad. Sci. USA 2009, 106, 17787-17792. [CrossRef]

92. Fridlyand, L.E.; Philipson, L.H. Reactive Species and Early Manifestation of Insulin Resistance in Type 2 Diabetes. Diabetes Obes. Metab. 2006, 8, 136-145. [CrossRef] [PubMed]

93. Evans, J.L.; Maddux, B.A.; Goldfine, I.D. The Molecular Basis for Oxidative Stress-Induced Insulin Resistance. Antioxid. Redox Signal. 2005, 7, 1040-1052. [CrossRef] [PubMed]

94. Cheng, Z.; Guo, S.; Copps, K.; Dong, X.; Kollipara, R.; Rodgers, J.T.; Depinho, R.A.; Puigserver, P.; White, M.F. Foxo1 Integrates Insulin Signaling with Mitochondrial Function in the Liver. Nat. Med. 2009, 15, 1307-1311. [CrossRef] [PubMed]

95. Zhang, K.; Kaufman, R.J. From Endoplasmic-Reticulum Stress to the Inflammatory Response. Nature 2008, 454, 455-462. [CrossRef] [PubMed]

96. Hotamisligil, G.S. Endoplasmic Reticulum Stress and the Inflammatory Basis of Metabolic Disease. Cell 2010, 140, 900-917. [CrossRef] [PubMed]

97. Ruzzin, J.; Petersen, R.; Meugnier, E.; Madsen, L.; Lock, E.J.; Lillefosse, H.; Ma, T.; Pesenti, S.; Sonne, S.B.; Marstrand, T.T; et al. Persistent Organic Pollutant Exposure Leads to Insulin Resistance Syndrome. Environ. Health Perspect. 2010, 118, 465-471. [CrossRef] [PubMed] 
98. Lv, Z.; Li, G.; Li, Y.; Ying, C.; Chen, J.; Chen, T.; Wei, J.; Lin, Y.; Jiang, Y.; Wang, Y.; et al. Glucose and Lipid Homeostasis in Adult Rat is Impaired by Early-Life Exposure to Perfluorooctane Sulfonate. Environ. Toxicol. 2013, 28, 532-542. [CrossRef]

99. Gray, S.L.; Shaw, A.C.; Gagne, A.X.; Chan, H.M. Chronic Exposure to PCBs (Aroclor 1254) Exacerbates Obesity-Induced Insulin Resistance and Hyperinsulinemia in Mice. J. Toxicol. Environ. Health A 2013, 76, 701-715. [CrossRef]

100. Ibrahim, M.M.; Fjaere, E.; Lock, E.J.; Naville, D.; Amlund, H.; Meugnier, E.; Le Magueresse Battistoni, B.; Froyland, L.; Madsen, L.; Jessen, N.; et al. Chronic Consumption of Farmed Salmon Containing Persistent Organic Pollutants Causes Insulin Resistance and Obesity in Mice. PLoS ONE 2011, 6, e25170. [CrossRef]

101. McLachlan, J.A.; Korach, K.S. Symposium on Estrogens in the Environment, III. Environ. Health Perspect. 1995, 103, 3-4. [CrossRef]

102. Enan, E.; Lasley, B.; Stewart, D.; Overstreet, J.; Vandevoort, C.A. 2, 3, 7, 8-Tetrachlorodibenzo-P-Dioxin (TCDD) Modulates Function of Human Luteinizing Granulosa Cells Via cAMP Signaling and Early Reduction of Glucose Transporting Activity. Reprod. Toxicol. 1996, 10, 191-198. [CrossRef]

103. Enan, E.; Matsumura, F. 2, 3, 7, 8-tetrachlorodibenzo-p-dioxin (TCDD)-induced Changes in Glucose Transporting Activity in Guinea Pigs, Mice, and Rats in Vivo and in Vitro. J. Biochem. Toxicol. 1994, 9, 97-106. [CrossRef] [PubMed]

104. Olsen, H.; Enan, E.; Matsumura, F. Regulation of Glucose Transport in the NIH 3T3 L1 Preadipocyte Cell Line by TCDD. Environ. Health Perspect. 1994, 102, 454-458. [CrossRef] [PubMed]

105. Liu, P.C.; Matsumura, F. Differential Effects of 2,3,7,8-Tetrachlorodibenzo-P-Dioxin on the "Adipose- Type" and "Brain-Type" Glucose Transporters in Mice. Mol. Pharmacol. 1995, 47, 65-73. [PubMed]

106. Hotamisligil, G.S.; Arner, P.; Caro, J.F.; Atkinson, R.L.; Spiegelman, B.M. Increased Adipose Tissue Expression of Tumor Necrosis Factor-Alpha in Human Obesity and Insulin Resistance. J. Clin. Investig. 1995, 95, 2409-2415. [CrossRef] [PubMed]

107. Uysal, K.T.; Wiesbrock, S.M.; Marino, M.W.; Hotamisligil, G.S. Protection from Obesity-Induced Insulin Resistance in Mice Lacking TNF-A Function. Nature 1997, 389, 610-614. [PubMed]

108. Wu, H.; Yu, W.; Meng, F.; Mi, J.; Peng, J.; Liu, J.; Zhang, X.; Hai, C.; Wang, X. Polychlorinated Biphenyls-153 Induces Metabolic Dysfunction through Activation of ROS/NF-кB Signaling Via Downregulation of HNF1b. Redox Biol. 2017, 12, 300-310. [CrossRef]

109. Kim, H.Y.; Kwon, W.Y.; Kim, Y.A.; Oh, Y.J.; Yoo, S.H.; Lee, M.H.; Bae, J.Y.; Kim, J.; Yoo, Y.H. Polychlorinated Biphenyls Exposure-Induced Insulin Resistance is Mediated by Lipid Droplet Enlargement through Fsp27. Arch. Toxicol. 2017, 91, 1-11. [CrossRef]

110. Kim, Y.A.; Kim, H.Y.; Oh, Y.J.; Kwon, W.Y.; Lee, M.H.; Bae, J.Y.; Woo, M.S.; Kim, J.; Yoo, Y.H. Polychlorinated Biphenyl 138 Exposure-Mediated Lipid Droplet Enlargement Endows Adipocytes with Resistance to TNF-A-Induced Cell Death. Toxicol. Lett. 2018, 292, 55-62. [CrossRef]

111. Baker, N.A.; English, V.; Sunkara, M.; Morris, A.J.; Pearson, K.J.; Cassis, L.A. Resveratrol Protects Against Polychlorinated Biphenyl-Mediated Impairment of Glucose Homeostasis in Adipocytes. J. Nutr. Biochem. 2013, 24, 2168-2174. [CrossRef]

(C) 2019 by the authors. Licensee MDPI, Basel, Switzerland. This article is an open access article distributed under the terms and conditions of the Creative Commons Attribution (CC BY) license (http://creativecommons.org/licenses/by/4.0/). 